\title{
CONTROL OF THE TWO DOF INVERTED PENDULUM
}

\author{
Muhammad Fajar \\ Jurusan Teknik Mesin Universitas Mataram \\ Email: muh.fajar10@gmail.com
}

\begin{abstract}
This paper describes how to simulate and control the two DoF inverted pendulum system, a dynamics of multibody system. The control strategy used is based on the conventional feedback method for the stabilisation of the two DoF inverted pendulum system. Simulation study has been done shows that conventional method i.e. pole placement control strategy is capable to control multi input and multi output of the two DoF inverted pendulum system successfully. The result shows that pole placement control strategy gives satisfactory response that is presented in time domain.
\end{abstract}

Keywords: Inverted Pendulum, Pole Placement Control, Dynamic System, Multybody System

\begin{abstract}
Abstrak
Pada tulisan ilmiah ini dijelaskan bagaimana teknik mensimulasikan dan mengendalikan sebuah sistem pendulum terbalik dua derajat kebebasan yang merupakan sebuah sistem multi bodi yang sangat dinamis. Teknik pengendalian yang dipergunakan untuk menstabilkan sistem pendulum terbalik dua derajat kebebasan pada penelitian ini adalah teknik umpan balik yang umum dipergunakan dalam ilmu kontrol yaitu teknik penempatan akar persamaan (pole placements control strategy). Hasil simulasi yang telah dilakukan menunjukkan bahwa teknik penempatan akar persamaan ini dapat mengendalikan dengan baik sebuah sistem pendulum terbalik dengan dua derajat kebebasan yang merupakan sistem multi input dan multi output. Tingkat pengendalian terhadap sistem juga sangat memuaskan, hal ini dapat dilihat dari grafikgrafik hasil simulasi yang disajikan dalam kurva setiap variable sistem terhadap waktu.
\end{abstract}

Kata Kunci: Pendulum Terbalik, Pole Placement Control, Sistem Dinamis, Sistem Multi Bodi

\section{Introduction}

A cart mounted inverted pendulum is relatively simple mechanical system which is inherently unstable and defined by highly nonlinear dynamic equations [1]. The inverted pendulum model has been widely used as a teaching aid and in research experiments around the world. It is a suitable process to test prototype controllers due to its high non-linearities and lack of stability [2]. It is well established benchmark problem that provides challenging problems to control design.

To understand fundamental building of the dynamic of the inverted pendulum system is started by undertaking the simulation of common or classic inverted pendulum system as shown in Figure 1. This model system is simpler as it only has two DoF: one DoF rotation moving of the pendulum and one DoF horizontally moving of the cart [3]. A fundamental of this works is to investigate and demonstrate the use of conventional or classical control theory which is based on the input-output relationship to control very dynamic unstable system such as inverted pendulum. For the inverted pendulum system, the pendulum angle and the cart velocity or position need to be controlled and thus requires a multi-output system which is relatively simple to solve with state space method. Thus in this paper will be derived the mathematical model of the inverted pendulum in the state space form with pole placement or pole assignment control technique for controlling the cart velocity to follow on the desired velocity while maintaining the angle of the pendulum as $0^{\circ}$ (upright pendulum position).

\section{Mathematical Modelling}

The system consists of an inverted pole with mass, $m$, hinged by an angle $\theta$ from vertical axis on a cart with mass, $M$, which is free to move in the $x$ direction as shown in Figure 1. A force, $F$, is required to push the cart horizontally and dynamic equations relationship between the cart and 
inverted pendulum are required so that it is possible to keep the pendulum upright stable while the cart moves by following a set reference of velocity point or desired path.

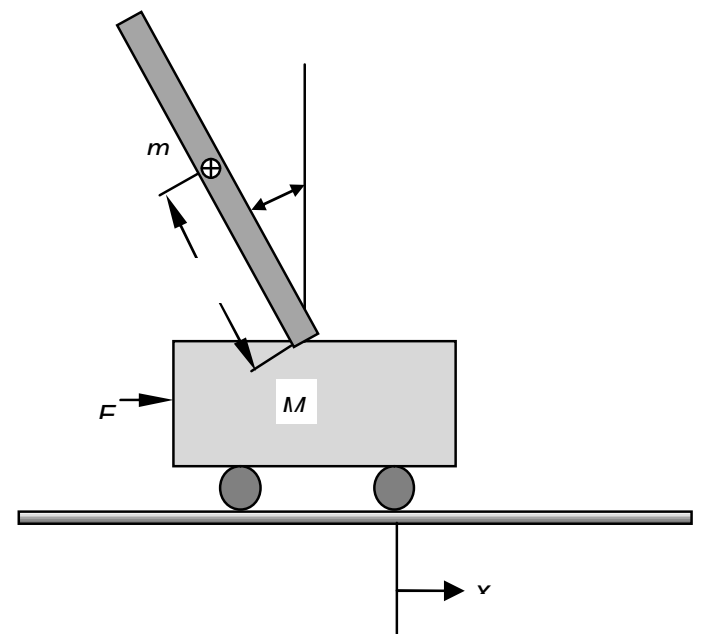

Figure 1 The two DoF inverted pendulum system

To derive dynamic equations or mathematical model for an inverted pendulum system considers the free body diagram shown in figure 2 .

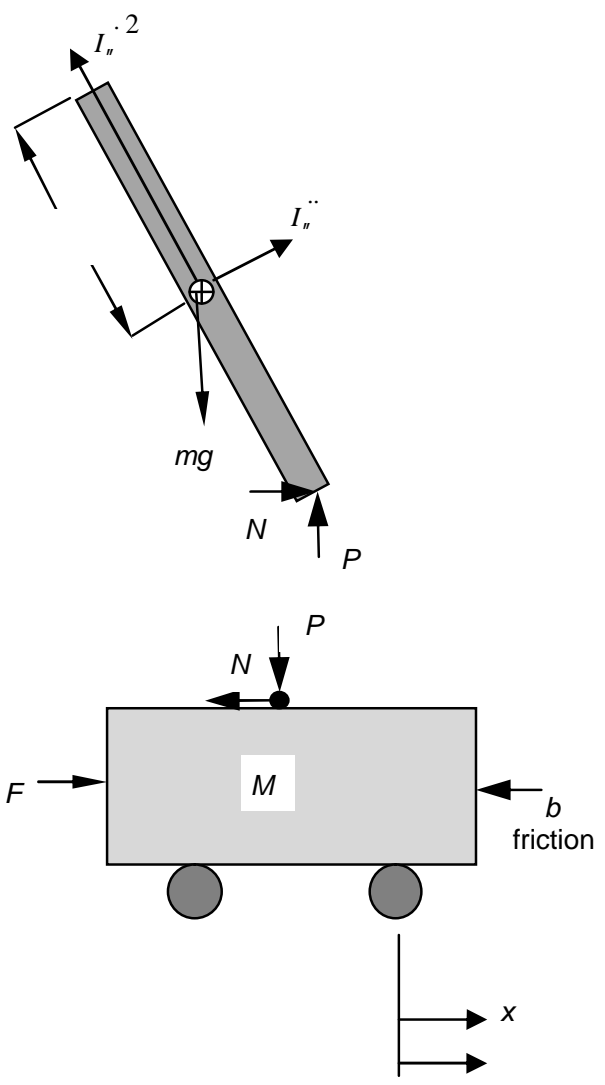

Figure 2 Free body diagram of the system
Summing forces of the cart in horizontal direction, based on the Newton law get:

$M \ddot{x}+b \dot{x}+N=F$

Summing forces of the pendulum in horizontal direction:

$$
m \ddot{x}+m l \ddot{\theta} \cos \theta-m l \dot{\theta}^{2} \sin \theta=N
$$

Substituting $N$ in equation (2) into equation (1) get the first dynamic equation for the system:

$(M+m) \ddot{x}+b \dot{x}+m l \ddot{\theta} \cos \theta-m l \dot{\theta}^{2} \sin \theta=F$

Summing forces perpendicular to the pendulum:

$P \sin \theta+N \cos \theta-m g \sin \theta=m l \ddot{\theta}+m \ddot{x} \cos \theta$

Summing moments around CG of the pendulum gets:

$-P l \sin \theta-N l \cos \theta=I \theta$

Combining equations (4) and (5) get the second dynamic equation for the system:

$\left(I+m l^{2}\right) \ddot{\theta}+m g l \sin \theta=-m l \ddot{x} \cos \theta$

Since the inverted pendulum must be kept on vertical, therefore it is assumed that $\theta(t)$ and $\dot{\theta}(t)$ are very small quantities such that $\sin \theta \approx \theta, \quad \cos \theta=-1 \quad$ and $\quad \dot{\theta} \dot{\theta}=0$. Thus dynamic equations above will become (where $u$ represent input):

$$
\begin{aligned}
& \left(I+m l^{2}\right) \ddot{\theta}-m g l \theta=m l \ddot{x} \\
& (M+m) \ddot{x}+b \dot{x}-m l \ddot{\theta}=u
\end{aligned}
$$

To build state space modelling of the system, the task is to derive the elements of the matrices, and to write the system model in the form:

$$
\begin{aligned}
& =A x+B u \\
y & =C x+D u
\end{aligned}
$$

The matrices $A$ and $B$ are properties of the system and are determined by the system structure and elements. The output equation matrices $C$ and $D$ are determined by the particular choice of output variables. 
To get state space model form of the inverted pendulum system, we need to eliminate $\ddot{\theta}$ from dynamic equations (7) and (8) to get equation for $\ddot{x}$ and vice versa as below. Eliminating $\ddot{\theta}$ from equations (7) and (8) gives:

$$
\begin{aligned}
& \ddot{x}=\frac{-\left(I+m l^{2}\right) b}{I(M+m)+M m l^{2}} \dot{x}+\frac{m^{2} g l^{2}}{I(M+m)+M m l^{2}} \theta \\
& +\frac{I+m l^{2}}{I(M+m)+M m l^{2}} u
\end{aligned}
$$

Eliminating $\ddot{x}$ from equations (7) and (8) gives:

$$
\begin{aligned}
& \ddot{\theta}=\frac{-m l b}{I(M+m)+M m l^{2}} \dot{x}+\frac{m g l(M+m)}{I(M+m)+M m l^{2}} \theta \\
& +\frac{m l}{I(M+m)+M m l^{2}} u
\end{aligned}
$$

Define state variables, with $x_{1}=x$ and $x_{3}=\theta$, can be obtained from equations (11) and (12) as:

$$
\begin{aligned}
& \dot{x}_{1}=x_{2} \\
& \dot{x}_{2}=\frac{-\left(I+m l^{2}\right) b}{I(M+m)+M m l^{2}} x_{2}+\frac{m^{2} g l^{2}}{I(M+m)+M m l^{2}} x_{3} \\
& +\frac{I+m l^{2}}{I(M+m)+M m l^{2}} u \\
& \dot{x}_{3}=x_{4} \\
& \dot{x}_{4}=\frac{-m l b}{I(M+m)+M m l^{2}} x_{2}+\frac{m g l(M+m)}{I(M+m)+M m l^{2}} x_{3} \\
& +\frac{m l}{I(M+m)+M m l^{2}} u
\end{aligned}
$$

Then the state space equations can be presented as:

$$
\left[\begin{array}{l}
\dot{x}_{1} \\
\dot{x}_{2} \\
\dot{x}_{3} \\
\dot{x}_{4}
\end{array}\right]=\left[\begin{array}{cccc}
0 & -\left(I^{2}\right) b & m^{2} g l^{2} & 0 \\
0 & \frac{-\left(M l^{2} b\right.}{I(M+m)+M m l^{2}} & \frac{0}{I(M+m)+M m l^{2}} & 0 \\
0 & 0 & 0 & 1 \\
0 & \frac{-m l b}{I(M+m)+M m l^{2}} & \frac{m g(M+m)}{I(M+m)+M m l^{2}} & 0
\end{array}\right]\left[\begin{array}{c}
x_{1} \\
x_{2} \\
x_{3} \\
x_{4}
\end{array}\right]
$$

$$
\begin{aligned}
& +\left[\begin{array}{c}
0 \\
\frac{I+m l^{2}}{I(M+m)+M m l^{2}} \\
0 \\
\frac{m l}{I(M+m)+M m l^{2}}
\end{array}\right] u \\
& {\left[\begin{array}{l}
y_{1} \\
y_{2}
\end{array}\right]=\left[\begin{array}{llll}
1 & 0 & 0 & 0 \\
0 & 0 & 1 & 0
\end{array}\right]\left[\begin{array}{l}
x_{1} \\
x_{2} \\
x_{3} \\
x_{4}
\end{array}\right]+\left[\begin{array}{l}
0 \\
0
\end{array}\right] u}
\end{aligned}
$$

\section{Pole Placement Control Strategy}

Controller of the pendulum system can be designed by using the controller design method of the pole placement or the pole assignment technique. The pole placement strategy is to put the poles of the closed loop system on the desired location by the state feedback through the appropriate state feedback gain matrix if the given system is perfectly controllable. When the system model is given as shown in the formula:

$$
\dot{x}=A x+B u
$$

The state feedback controller is as:

$u=-K x$

This means that the control signal $u$ is determined by an instantaneous state. It called state feedback. The state feedback gain matrix $K$ that is to design the controller has dimension $1 \times n$ and $n$ is the number of the state. Substitute equation (15) into equation (16) the result is:

$$
\dot{x}(t)=(A-B K) x(t)
$$

The solution of this equation is given by:

$$
x(t)=e^{(A-B K) t} x(0)
$$

Where, $x(0)$ is the initial state caused by external disturbances. The stability and transient response characteristics are determined by the eigenvalues of matrix $A$ $B K$. If matrix $K$ is chosen properly, the matrix $A$ - $B K$ can be made an asymptotically stable matrix, and for all $x(0) \neq 0$, it is possible to make $x(\mathrm{t})$ approach 0 as $t$ approaches 
infinity. Schematic block diagram of this type of control system is shown in figure 3 .

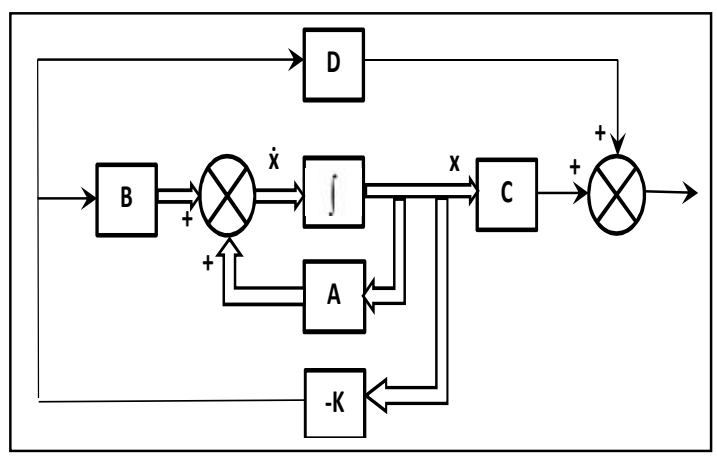

Figure 3 Schematic block diagram of closed loop control in state space form [4]

In this work to simulate the inverted pendulum system, let's assume the inverted pendulum properties are as:
$M$ mass of the cart $13.26 \mathrm{~kg}$
$m$ mass of the pendulum $2.88 \mathrm{~kg}$
$b$ friction of the cart $0.0 \mathrm{~N} / \mathrm{m} / \mathrm{sec}$
I length to pendulum CG $0.21 \mathrm{~m}$
I inertia of the pendulum $0.04 \mathrm{~kg}^{*} \mathrm{~m}^{2}$

Substituting all the inverted pendulum parameter values above into equations (13) and (14) and considering the cart position as outputs to the inverted pendulum state space model becomes:

$$
\begin{aligned}
& {\left[\begin{array}{c}
\dot{x}_{1} \\
\dot{x}_{2} \\
\dot{x}_{3} \\
\dot{x}_{4}
\end{array}\right]=\left[\begin{array}{cccc}
0 & 1 & 0 & 0 \\
0 & 0 & 1.5387 & 0 \\
0 & 0 & 0 & 1 \\
0 & 0 & 41.0617 & 0
\end{array}\right]\left[\begin{array}{c}
x_{1} \\
x_{2} \\
x_{3} \\
x_{4}
\end{array}\right]+\left[\begin{array}{c}
0 \\
0.0717 \\
0 \\
0.2596
\end{array}\right] u(19)} \\
& {[y]=\left[\begin{array}{llll}
1 & 0 & 0 & 0 \\
0 & 0 & 1 & 0
\end{array}\right]\left[\begin{array}{l}
x_{1} \\
x_{2} \\
x_{3} \\
x_{4}
\end{array}\right]+\left[\begin{array}{l}
0 \\
0
\end{array}\right] u}
\end{aligned}
$$

The poles of this model are:

$$
p=\begin{array}{llll}
0 & 0 & 6.4079 & -6.4079
\end{array}
$$

As can be seen there is a one pole laying in the right hand plane at 6.4079 thus the system is open loop very unstable. To stabilise the dynamics of the inverted pendulum plant obviously requires some of feedback controllers to be designed. This problem can be solved by finding a suitable $K$ matrix using a full state feedback type 1 servo system. The schematic block diagram of this control is as shown in Figure 4 below.

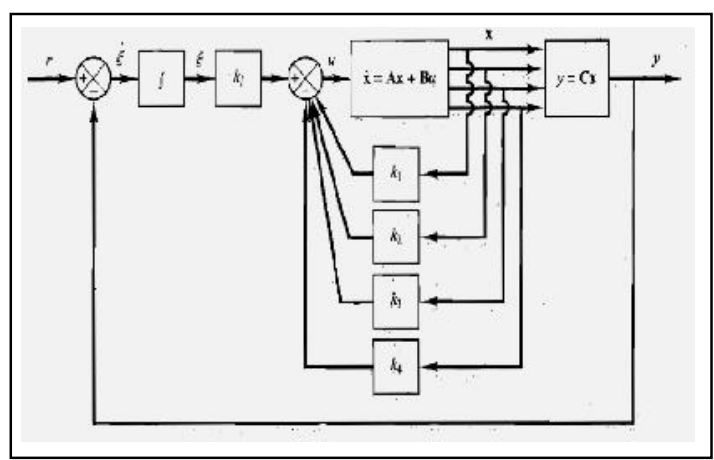

Figure 4 Full state feedback type 1 servo system [4]

Where $r$ represents the reference input signal to the cart. The four states $\left(x_{1}, x_{2}, x_{3}, x_{4}\right)$ represent position of the cart, velocity of the cart, pendulum's angle and angular velocity of the pendulum and $y$ represents the output signal. A controller have to be designed so that when reference input is given to the system, the pendulum should be displaced, but eventually return to zero (upright) and the cart should move with its position or velocity as commanded in the reference input.

In the pole placement method, pole locations can be arbitrarily placed if and only if the inverted pendulum plant is controllable. Therefore the controllability matrix of the plant is determined first before calculating the feedback gain matrix $K$. The controllability matrix is given as:

$$
M=\left[\begin{array}{lllll}
B & A B & A^{2} B & \ldots & A^{n-1} B
\end{array}\right]
$$

If $M$ is nonzero the plant is controllable From the equation (19) the state space model get:

$$
A=\left[\begin{array}{cccc}
0 & 1 & 0 & 0 \\
0 & 0 & 1.5387 & 0 \\
0 & 0 & 0 & 1 \\
0 & 0 & 41.0617 & 0
\end{array}\right] \text { and } B=\left[\begin{array}{c}
0 \\
0.0717 \\
0 \\
0.2596
\end{array}\right]
$$

Since the controllability matrix $M$ is given by: 


$$
\begin{aligned}
& M=\left[\begin{array}{llcc}
B & A B & A^{2} B & A^{3} B
\end{array}\right] \\
& =\left[\begin{array}{cccc}
0 & 0.0717 & 0 & 0.3994 \\
0.0717 & 0 & 0.3994 & 0 \\
0 & 0.2596 & 0 & 10.6597 \\
0.2596 & 0 & 10.6597 & 0
\end{array}\right]
\end{aligned}
$$

And the determinant solution gives that $|M|=0.4362$, thus the inverted pendulum plant is controllable and arbitrary pole placement is possible.

Referring to figure 4 the state feedback control law for the inverted pendulum with set point or tracking is:

$$
\begin{aligned}
& u=-K x+k_{I} \xi \\
& \xi=r-y
\end{aligned}
$$

In which $r$ is the input signal reference to be tracked by $y$, thus $\xi$ represents integral of the tracking error. For type servo system 1 state error equations is given as:

$\dot{e}=\hat{A} e+\hat{B} u_{e}$

Where,

$$
\begin{aligned}
& \hat{A}=\left[\begin{array}{cc}
A & 0 \\
-C & 0
\end{array}\right]=\left[\begin{array}{ccccc}
0 & 1 & 0 & 0 & 0 \\
0 & 0 & 1.5387 & 0 & 0 \\
0 & 0 & 0 & 1 & 0 \\
0 & 0 & 41.0617 & 0 & 0 \\
-1 & 0 & 0 & 0 & 0
\end{array}\right], \\
& \hat{B}=\left[\begin{array}{l}
B \\
0
\end{array}\right]=\left[\begin{array}{c}
0 \\
0.0717 \\
0 \\
0.2596 \\
0
\end{array}\right]
\end{aligned}
$$

The control signal is given by equation:

$u_{e}=-\hat{K} e$

Where,

$\hat{K}=\left\lfloor\begin{array}{ll}K & -k_{I}\end{array}\right\rfloor=\left\lfloor\begin{array}{lllll}k_{1} & k_{2} & k_{3} & k_{4} & -k_{I}\end{array}\right\rfloor$

In order to get a reasonable speed and damping in the response of the designed inverted pendulum plant system, the desired closed-loop poles were chosen to be at $s=\mu_{i}$ $(i=1,2,3,4.5)$, where: $\mu_{1}=-7+7 \mathrm{i}, \mu_{2}=-7-7 \mathrm{i}, \mu_{3}=-7, \mu_{4}=-7, \mu_{5}=-7$

And the state-feedback gain matrix is calculated by using the Ackerman command to calculate the state feedback gain matrix $K$. The calculation gives result feedback gains to control the designed inverted pendulum system as:

$$
\begin{aligned}
& \hat{K}=\left[K, k_{i}\right]=\left[k_{1}, k_{2}, k_{3}, k_{4}, k_{i}\right] \\
& =\left[\begin{array}{lllll}
-4714.2 & -1533.4 & 3347.2 & 558.3 & 6595.7
\end{array}\right]
\end{aligned}
$$

\section{Result}

The simulation result when the step response input gives to the system is as shown in Figure 5. The graph shows that the pendulum rod can be stabilised at zero point at about 2 seconds while the cart can be stabilised successfully as well and reaches the new position as the reference input at $1 \mathrm{~m}$.

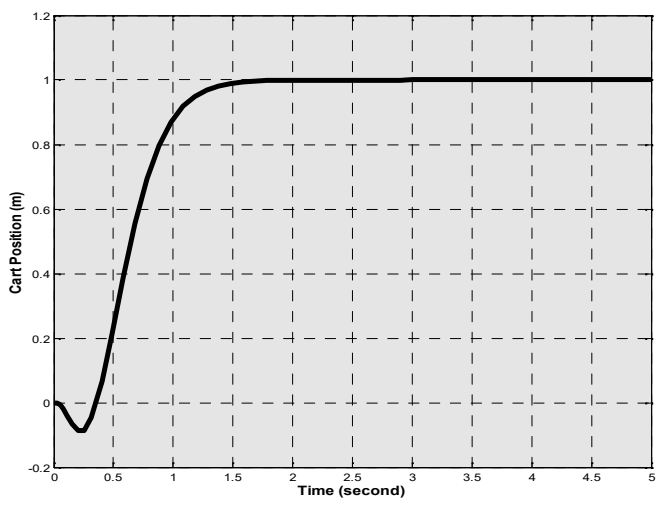

(a) Cart Position $x$

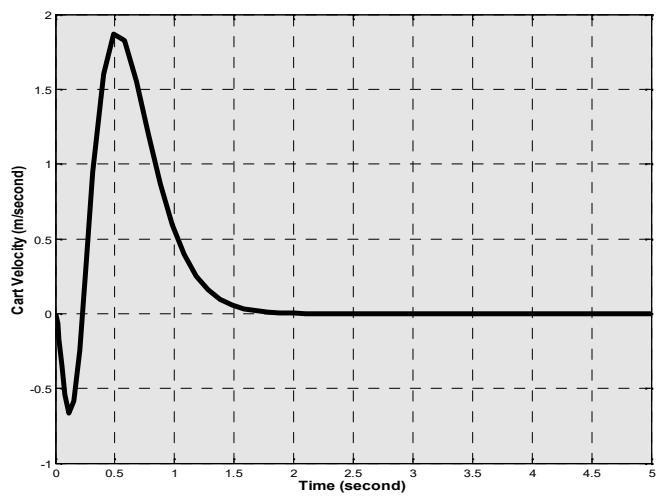

(b) Cart Velocity $x_{2}$ 


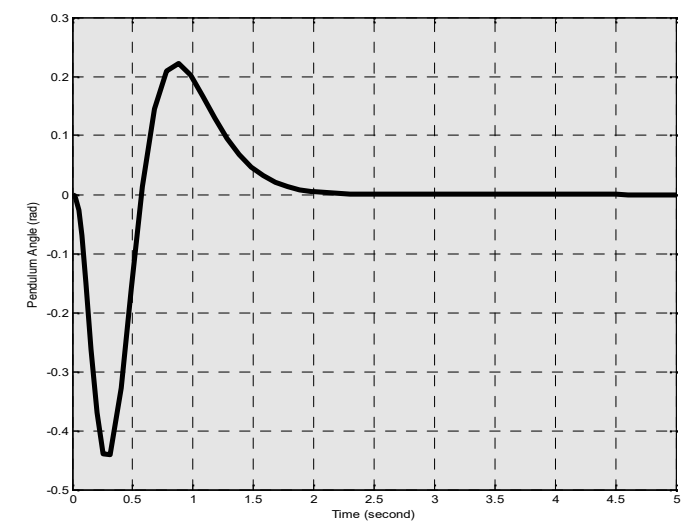

(c) Pendulum Angle $x_{3}$

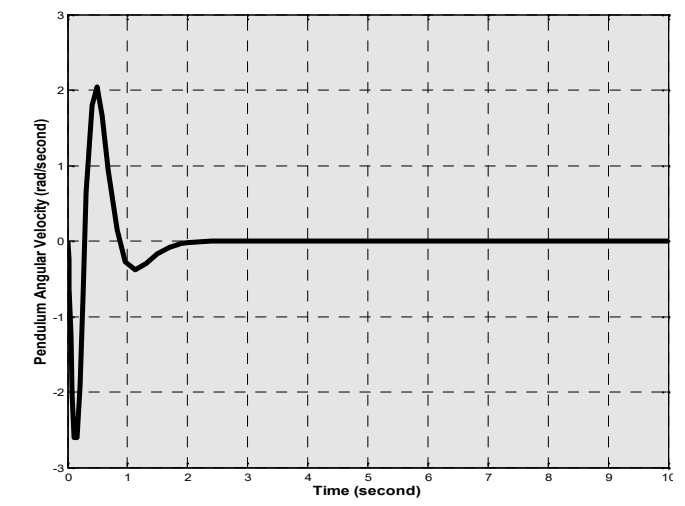

(d) Pendulum Angular Velocity $x_{4}$

Figure 5 Simulink state variables step response

When the cart is given a prescribed velocity, the state variables response result is as shown in Figure 6.

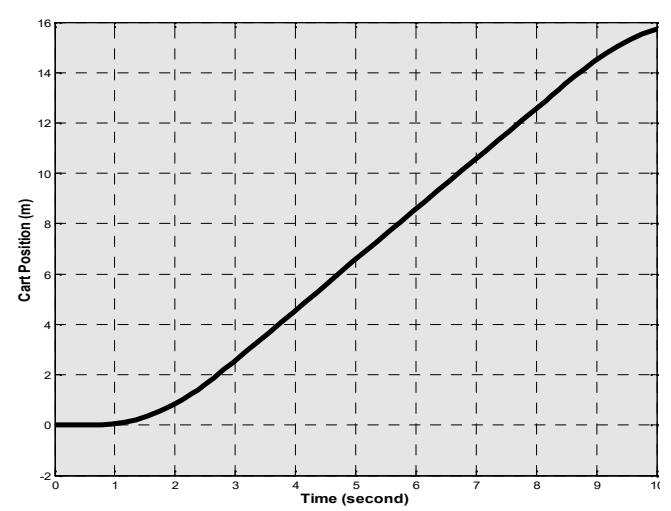

(a) Cart Position $x_{1}$

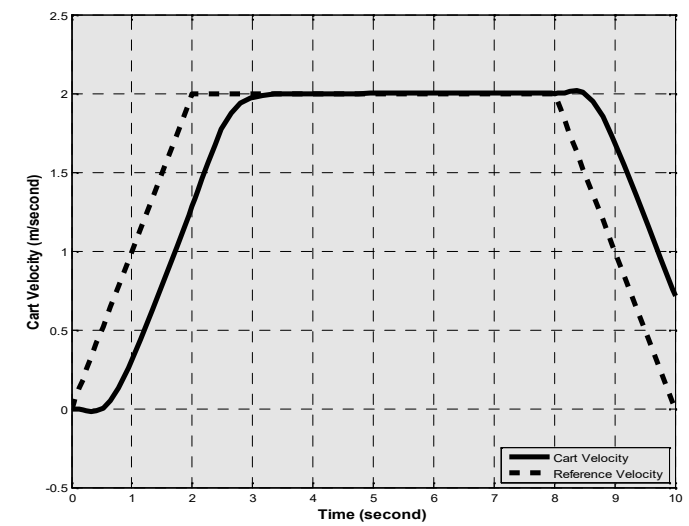

(b) Cart Velocity $x_{2}$

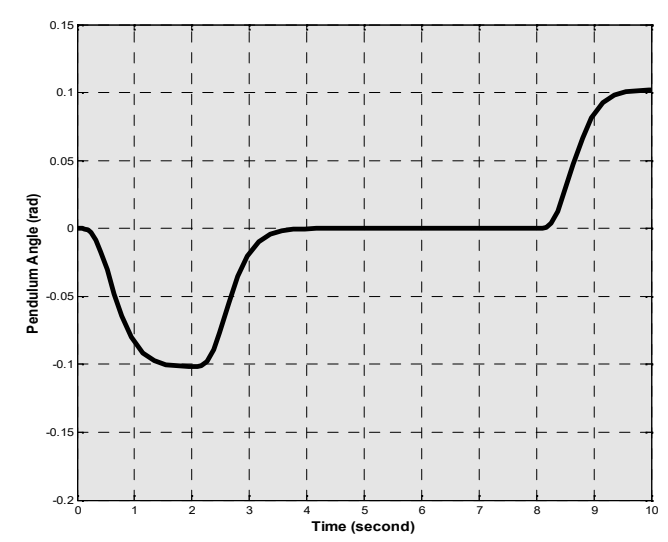

(c) Pendulum Angle $x_{3}$

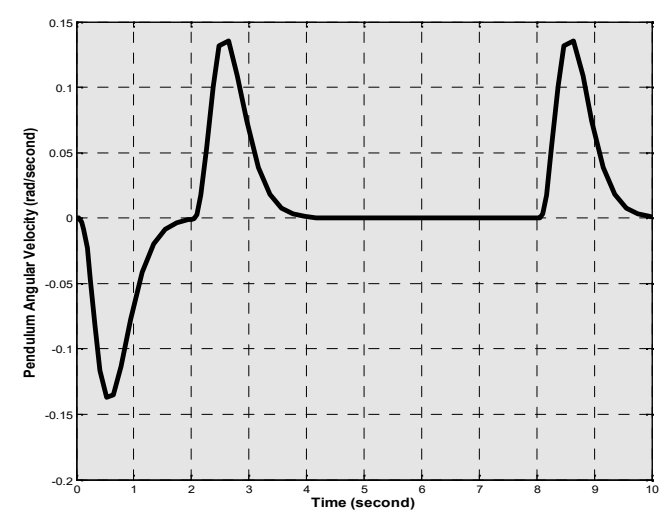

(d) Pendulum Angular Velocity $x_{4}$

Figure 6. Simulink state variables result for cart velocity reference 
This graph shows that the cart velocity lags about 0.5 seconds from the cart velocity reference. However the cart velocity can be controlled successfully to track the reference given while at the same time stabilised the angle pendulum rod in upright position.

\section{Conclusion}

Based on simulation results, it can be said that the pole placement method can be useful to design controllers for the two DoF inverted pendulums with satisfactory performance. The result shows that pole placement is capable of controlling the two DoF inverted pendulum's angle and the cart's position or velocity. But a problem still exists when the two DoF inverted pendulum system is given a prescribed velocity this leads to the cart's velocity lagging the input by about 0.5 second.

\section{References}

[1] J. J. Wang, Simulation Studies of Inverted Pendulum based on PID Controllers, Simulation Modelling Practice and Theory, vol. 19, pp. 440-449, Elsevier (2011).

[2] J. Hauser, S. Alesandro and F. Ruggero, On the Driven Inverted Pendulum; 44th IEEE Conference on Decision and Control; Dec 12 - 15 2005; Seville, Spain. 6176-6180.

[3] R. Yang, Y. Kuen and Z. Li, Stabilization of a 2-DOF spherical pendulum on $X-Y$ Table. Proceedings of the 2000 IEEE international conference on control and applications, Anchorage Alaska USA,September 2000; 724-729

[4] OGATA K. (2002) Modern Control Engineering. Publisher: Prentice Hall of India, ISBN-10:812032045X, fourth edition. 